\title{
2006-1386: THE GLOBAL RELEVANCE OF BIO-BASED INDUSTRIES TO ENGINEERING AND TECHNOLOGY EDUCATION
}

\section{Kurt Rosentrater, USDA-ARS}

KURT A ROSENTRATER is a Lead Scientist with the United States Department of Agriculture, Agriculture Research Service, as well as an Adjunct Assistant Professor in the Department of Agricultural and Biosystems Engineering, South Dakota State University, in Brookings, SD, where he is spearheading a new initiative to develop value-added uses for residue streams resulting from biofuel manufacturing operations. He is formerly an Assistant Professor at Northern Illinois University, DeKalb, IL, in the Department of Technology.

\section{Radha Balamuralikrishna, Northern Illinois University}

RADHA BALAMURALIKRISHNA has an educational background in engineering, industrial education, and business administration. He is a licensed professional engineer in the State of Illinois. He received the Faculty of the Year award in 2000 sponsored by the College of Engineering and Engineering Technology. His primary areas of expertise are computer-aided design and process improvement methodologies. 


\title{
THE GLOBAL RELEVANCE OF BIO-BASED INDUSTRIES TO ENGINEERING AND TECHNOLOGY EDUCATION
}

\begin{abstract}
The society in which we live has developed an insatiable demand for energy and material goods. In particular, recent data reveals that the aggressive pursuit of improved standards of living in the highly populated countries of India and China has contributed to increased demand for fossil fuels, which has exacerbated the recent spike in energy costs. Historically, these needs have been met primarily by fossil fuels and other non-renewable raw materials. As environmental concerns grow, however, renewable resources are gaining increased attention. This paper examines the emergence and importance that bio-based industries are increasingly beginning to play. A bio-based enterprise, similar in concept to a traditional refinery or factory, utilizes conversion technologies to produce various products. Bio-based refining and manufacturing operations are rapidly increasing both in number as well as in capacity throughout this country, and are poised to add significantly to the nation's energy and material supplies in coming years. Therefore, to adequately prepare engineering and technology graduates for the opportunities presented by bio-based industries, it is vital for these graduates to understand this developing industrial segment and its fundamental concepts. Toward this end, this paper will discuss several essential topics, including national production and consumption information for chemicals, fuels, and manufactured products; production data, trends, and growth potential for bio-based industries; similarities between traditional refining and manufacturing industries to bio-based industries; tools essential for success, including quality improvement, management, and business productivity tools; relevance to engineering and technology education; and curriculum modification and incorporation techniques that can be used to achieve these efforts. The trends discussed here and their implications are critical for educators, because in coming years these industries will be used to simultaneously meet the needs of our society as well as that of environmental stewardship.
\end{abstract}

\section{Keywords}

Biochemicals, Biofuels, Biomass, Bioprocessing, Biopower, Bioproducts, Biorefining, Curriculum Development

\section{Introduction}

Successful manufacturing and industrial enterprises often have a history of adapting to change as markets, and the forces that drive them, dynamically shift over time. The importance of flexibility and openness to change has been emphasized repeatedly if companies are going to succeed and grow, especially when faced with difficult choices of how best to adapt, and inevitably alter business practices, strategies, resources, facilities, locations, or even labor practices. Thus national, and increasingly global, changes can present many opportunities and challenges for both employers and employees. 
Throughout history, the disciplines of engineering and technology have emphasized the application of scientific principles for the benefit of society. From the inception of this country, engineering and technology have been cornerstones upon which the U.S. has flourished. With this growth over the years, coupled with increasing industrialization, population, and consumption, several critical challenges have arisen. These include pollution, environmental degradation, raw material depletion, increasing dependence on foreign supplies of nonrenewable resources, and national security concerns, to name a few.

For example, the quantity of oil imported into the U.S. for transportation fuels has been steadily increasing during the last 20 years (Figure 1); now the nation is highly dependent on imported oil. In fact, it currently imports more than $60 \%$ of its yearly petroleum requirements.

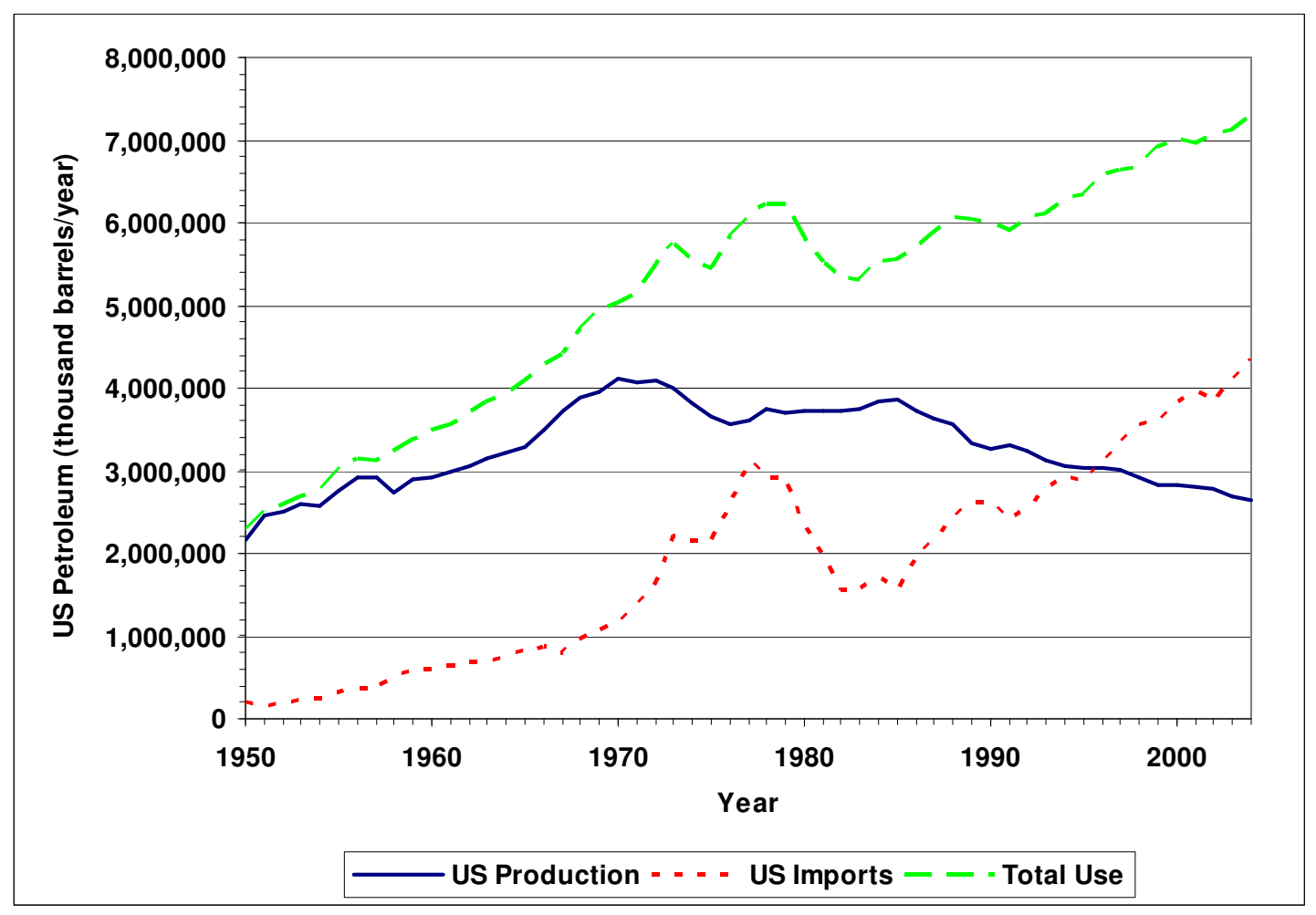

Figure 1. Trends in U.S. oil supply and demand [adapted from 1].

Another example is overall national energy consumption. Figure 2 depicts the history of U.S. energy in terms of total energy used, as well as the energy consumed from the primary fossil fuel and nuclear power sectors. Other than two slight declines (in the mid-1970s and the early 1980s) in response to energy crises, energy consumption has increased steadily. This is due, in part, to the advent of the micro computer, the information and technology revolution, the ubiquitous SUV, as well as increasing productivity in the industrial sector, not to mention population growth. Consequently, the consumption of all fossil fuels has also been increasing over time in order to meet this increasing demand. Petroleum has historically been the single greatest energy source in the U.S., so its consumption (as shown in Figure 1) closely parallels that of total energy consumption, at least up until the mid-1980s. After that point in time, the rate of increase for total energy has been greater than that provided by petroleum alone, as evidenced by the slope of 
the consumption curves. Nuclear, coal, and natural gas are increasingly being used to help meet this increasing demand. Moreover, the hurricanes of 2005 clearly illustrated to many how volatile the energy markets currently are, and how dependent we are upon them.

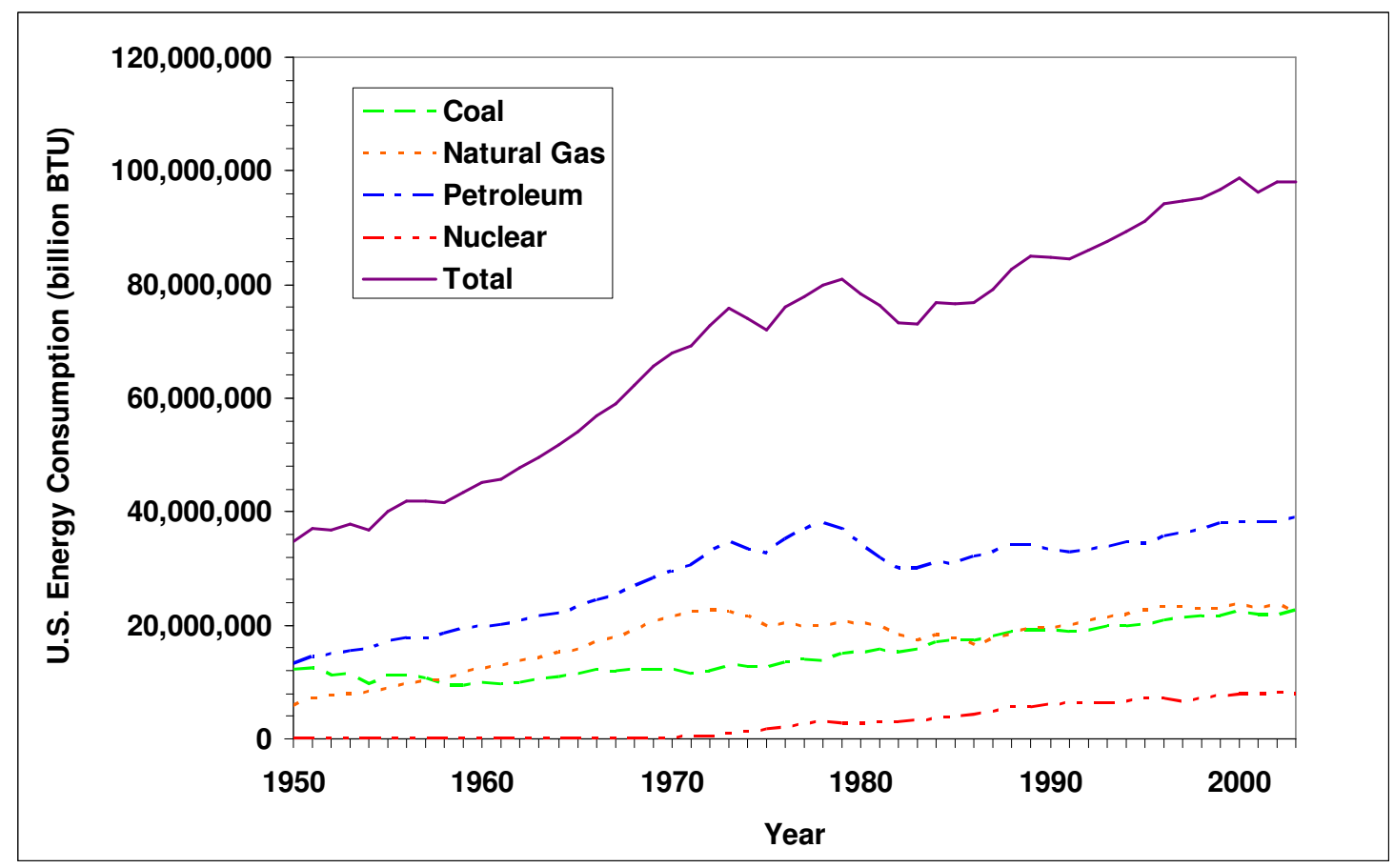

Figure 2. Trends in U.S. energy consumption [adapted from 1].

Our nation, and in fact the entire world, are on the cusp of very real changes, however. Tremendous advances in science and engineering over the last several decades have substantially enhanced the ability to utilize renewable, biological materials. Biomass conversion technologies are now practical and affordable for a variety of bio-based products, and they offer many opportunities to decrease our dependence on nonrenewable resources. Bio-based industries are poised to contribute substantially to the supply of energy, transportation fuels, industrial chemicals, and manufactured products in coming years. These trends are reflected in many federal initiatives within both the Department of Energy (www.doe.gov) and the Department of Agriculture (www.usda.gov). Prominent topics currently include ethanol, biodiesel, novel processing technologies, including enzymatic and microbial conversions, gasification of biomass, lignocellulose (e.g., corn stover, switchgrass, and woody crop) production, transportation, storage, and processing technologies, and even hydrogen production from biomass. Some of these topics will be discussed more thoroughly below. For additional information, the reader is referred to the aforementioned websites.

These potential changes are being realized in the marketplace. E10 and E85 gasoline blends are prime examples of this progress. As bio-based products continue to gain prevalence, there will be a growing need for trained personnel to design and operate facilities to produce these biologically-based products, as well as design the products themselves, and ensure their quality during manufacture. Engineering and technology educators currently have an exciting 
opportunity to expand their mission to address biological processing and manufacturing, and to contribute to this coming wave of change in the industry.

Therefore, the objective of this paper is to introduce engineering and technology educators to this emerging area so that existing curricula can be augmented. Toward that end, several essential topics will be discussed, including biomass resources, biobased industries (including bioenergy, biofuels, and bioproducts), the relevance to engineering and technology education, common tools essential for the success of both traditional and biobased manufacturing, resources for educators, and strategies to use the information presented here to bolster current practice in education.

\section{Biomass Resources}

Globally, tremendous quantities of biomass are produced annually [2]. It is estimated that in the U.S. alone, between 1.8 and 3.2 billion dry tons are produced each year, which equates to potential bioenergy production of between 34 and 60 trillion GJ [3]. Further, it is estimated that worldwide potential for production of biomass energy could reach up to $1135 \mathrm{EJ} / \mathrm{y}$ during the next 50 years [4]. When processing biological materials, one of the main goals is to target the carbohydrates that are in these raw product streams, especially the lignocellulose matrix, because they can be converted into a range of valuable chemicals, chemical intermediates, finished biobased products, biofuels, bioenergy, or foods and feeds. The following discussions will attempt to briefly capture some of the main concepts of using biological materials in manufacturing, but will not be completely exhaustive. More comprehensive treatments can be found in [3, 5-11], to which the reader is referred for more information.

Potential biomass sources include wastes as well as energy crops. Waste streams include agricultural crop residues (e.g., stover, stalks, stems, leaves, cobs, etc.) which are left after harvest, municipal solid waste (MSW), especially the paper, food, and other organic waste constituents within the MSW, livestock waste (i.e., manure), and food processing wastes. Energy crops, on the other hand, are grown specifically to be used either for bioenergy conversion or manufacture into other bio-based products or fuels. Herbaceous crops, such as miscanthus, Napier grass, sorghum, reed canary grass, fescue, switchgrass, and sugarcane, can be harvested annually and can yield up to $30 \mathrm{Mg} / \mathrm{ha} / \mathrm{y}$, depending upon the species. Short-rotation woody crops, such as willow, poplar, maple, sycamore, and alder, can generally be harvested in 10 years or less, and can yield up to $43 \mathrm{Mg} / \mathrm{ha} / \mathrm{y}$. More information can be found in $[3,12]$.

\section{Emerging Bio-Based Industries}

In general, biomass streams cannot be utilized directly as bioenergy, biofuels, or bioproducts; they typically must undergo some type of conversion process in order to improve the often relatively poor characteristics vis-à-vis energy, fuel, or material precursors. These obstacles can include: 1) nonhomogeneity; 2) low to modest thermal content; 3) high moisture content; 4) low bulk density; and 5) material handling challenges. Conversion of biomass is typically accomplished via several sequential steps, including pre-treatment, hydrolysis, fermentation, and distillation, or it can be accomplished via thermochemical means. Pre-treatment processes, such as drying or grinding, and acid, enzymatic, or steam hydrolysis, are used to liberate sugars from the lignocellulose, and thus make the biomass suitable for subsequent fermentation. 
Fermentation is a process where microorganisms digest the carbohydrates, especially sugars and starches, and produce various end products, depending on the specific organisms, biomass source, and operational conditions used. Potential fermentation products include ethanol, lactic acid, and succinic acid. Distillation is then used to remove various water-soluble compounds. More information regarding industrial fermentation of biomass can be found in [13-16]. Thermochemical conversion, on the other hand, can include pyrolysis, where the biomass is heated in the absence of oxygen to produce a bio-oil, residual solids (known as char), and various gases (such as methane, carbon monoxide, and carbon dioxide), or liquefaction, where the biomass is converted at moderate temperatures and pressures into a liquid state. The end products produced via thermochemical conversion contain high concentrations of organic compounds, and thus are useful as concentrated precursors for further utilization. More information regarding thermochemical conversion of biomass can be found in [17-23].

Converted biomass can then be transformed into bioenergy, primarily in the form of heat or electric power (e.g., stationary generation). Often, however, it is only the residual lignin and cellulose components of the biomass that are used to produce bioenergy, because the other constituents are typically utilized for other higher-value uses, such as biofuels and bioproducts. Combustion, gasification, and anaerobic digestion are the three primary techniques that are commonly used to generate bioenergy. Combustion, which is the conversion of biomass into heat, can be accomplished in a variety of combustors, furnaces, and boilers. More information regarding combustion of biomass can be found in [24-26]. Gasification, which is the conversion of biomass into flammable gas using an atmosphere deficient in oxygen, can be accomplished in gasifiers, of which there are several types. More information regarding gasification can be found in [27-30]. Anaerobic digestion, which is the decomposition and conversion of biomass using microbes into flammable gas, can be accomplished in a variety of digesters. More information regarding anaerobic digestion can be found in [31-38]. The gas produced by gasifiers and anaerobic digesters can then be combusted and used to drive electricity generation turbines.

As a high-value utilization option, converted biomass can be processed into liquid fuels for automobiles. Biofuels, which are renewable sources of energy, can help meet increasing energy needs, and are produced from various biomass sources including residue straw, corn stover, perennial grasses and legumes, and other agricultural and biological materials. At the moment, however, the most heavily utilized is corn grain, because corn starch can be easily fermented into ethanol on an industrial scale. Although directly tied to the market value of the grain itself, industrial ethanol production from corn is readily accomplished at a relatively low cost vis-à-vis other biomass sources. In coming years, however, due to rapid technological advances, the hydrolysis and conversion of these other lignocellulosic materials is expected to become costcompetitive as this industry matures [39]. More information regarding the production of bioethanol can be found in [40-43]. Currently, bioethanol is the biofuel with greatest use in the U.S., but biodiesel is also poised to significantly contribute to the nation's energy supply in coming years. Biodiesel is produced by converting triglycerides into methyl or ethyl esters via chemical modification. Soybean, sunflower, safflower, cottonseed, and other oil seed crops are targeted for production of commercial biodiesel. More information regarding the manufacture of biodiesel can be found in [44-46]. 
Converted biomass can also be manufactured into many different industrial products, such as bio-based chemicals and biopolymers, which are prime targets for utilization. This includes finished products as well as intermediates which are precursors for further manufacture. At the moment, several important chemicals are currently manufactured from various biomass sources, including furfural, gluconic acid, lactic acid, mannitol, sorbitol, and xylitol. Moreover, several additional chemicals should be commercially-viable in the foreseeable future, including acetic acid, hydroxyacetaldehyde, levoglucosan, levulinic acid, and polyhydroxybutyrate. More information regarding the production of biochemicals can be found in [3, 35, 47-50]. The conversion of biological fibers into various products has been successfully advanced and highly utilized over the years in the pulp, paper, and textile industries. Fibers are, however, increasingly being used to develop novel biopolymers, biocomposites, and plastic reinforcements. Traditional plastics manufacturing operations, such as compression and injection molding, as well as extrusion processing, have been shown to be quite successful in developing these products. More information regarding production of biomaterials can be found in [51-53].

\section{Relevance to Engineering and Technology Education}

There are many similarities between traditional and bio-based manufacturing operations. Job categories involved in both of these types of industries require advanced technical education that is received via college training and preparation. Some of these include engineering and design, production and operations, research and development, quality management and improvement, information technology, marketing and sales, management, human resources, and even workplace safety and health. Thus, bio-based industries are very germane to engineering and technology disciplines. Bio-based operations require skill sets similar to traditional manufacturing settings, but also have a need for additional knowledge in biological sciences, which can vary according to the specific product(s) produced at a given facility (i.e., energy, fuels, chemical, or products). For example, equipment, processes, and unit operations must be designed; these systems must be optimized, modeled, and simulated; and their economics must be analyzed. Furthermore, facilities to house and service these processes, as well as humanmachine interfaces, must be designed and constructed. Thus, the fields of engineering and technology are fundamental to the successful design and deployment of these operations. Although specific engineering areas that will be vital to these ventures include Agricultural, Biological, Biochemical, Bioprocess, Chemical, Industrial, Manufacturing, Mechanical, and Structural, the reality of the matter is that all branches of engineering and technology will be required if these emerging industries are to succeed.

\section{Essential Engineering and Technology Tools}

Bio-based industries are highly process oriented. Therefore, a number of quality tools that are suitable for analyzing traditional manufacturing and related processes are directly relevant to biobased manufacturing. Quality tools such as Pareto charts, flowcharts, and histograms that help in problem identification are equally valid in both scenarios. Skills in the application of the causal identification tools and procedures such as the cause-and-effect diagram, root cause analysis, stratification, and correlation analysis can be seamlessly transferred as well. Arguably, the most important quality tool that would apply to bio-based manufacturing would be statistical process control charts based on the methods advocated by Walter Shewhart [73, 74], which have found 
universal appeal in traditional global manufacturing. Due to the inherent nature of the presence of a number of variables and possible varied levels of their existence involved in bio-based manufacturing, quality techniques such as the design of experiments and Taguchi studies [75] become highly relevant for process innovation and improvement. Knowledge in these and other basic quality principles is a prerequisite in most engineering and technology degree programs, so extending these concepts to include bio-based manufacturing can be accomplished with relative ease.

Management/business concepts such as strategic project planning, project scheduling, and project management are indispensable in the operation of successful bio-industries. The emerging ideas of supply chain management, including choice of location and layout, inventory control, transportation and logistics, and information systems will play a significant role in the growth and sustenance of bio-based products in society. There is a wide array of specific management tools in planning, scheduling, and control that have been in use in industry for decades, and new tools appear on a regular basis. Creative use of these tools is just as important for bio-based manufacturing as well and much work by way of documenting successful experience remains to be forthcoming.

Problem-solving tools are always an important part of the technologist's armor and bio-based industries lend themselves to the application of traditional problem solving models used in engineering and technology. The power of the typical six-step iterative approach to problem solving (i.e., problem definition, generation of ideas, refinement of ideas, analysis, decision, and implementation) need not be underestimated just because the context has changed from nonrenewable to renewable forms. The time honored principle of the plan-do-check-act methodology to attack problems and promote continuous improvement of processes remains valid in the new materials era as well.

\section{Resources for Educators}

Information regarding current and promising bio-based products and processes is quite dispersed; no single comprehensive literature source exists. For instructors who are interested in incorporating individual, specific modules into existing engineering or technology coursework at appropriate locations during the semester, as well as those who may design and implement entire courses devoted to the aforementioned topics, supporting teaching materials will be critical to these endeavors. Therefore, a thorough listing of recent textbooks and online publications has been compiled and is provided below in Table 1.

Table 1. Essential bio-based industry resources for educators.

\section{$\underline{\text { Books }}$}

Brown, R.C.. 2003. Biorenewable Resources - Engineering New Products from Agriculture. Blackwell Publishing Co. New York, NY.

Dokon, L. E. 2001. The Alcohol Fuel Handbook. Infinity Publishing.

Klass, D.L.. 1998. Biomass for Renewable Energy, Fuels, and Chemicals. Academy Press. New York, NY. 
Pahl, G. 2005. Biodiesel: Growing a New Energy Economy. Chelsea Green Publishing Company.

Sorensen, B. 2004. Renewable Energy. Academic Press.

Wyman, C. 1996. Handbook on Bioethanol: Production and Utilization. Taylor \& Francis.

\section{Online Publications}

Biobased Industrial Products: Research and Commercialization Priorities. 2000.

Commission on Life Sciences. http://books.nap.edu/books/0309053927/html/1.html

Bioenergy Terminology - Factsheet No. atlas_006. 2005. Zimmermann, L. and I. Nuberg. http://www.brs.gov.au/bioenergy_atlas/factsheets/Atlas_006.pdf\#search='Bioenergy\%20 Terminology'

Biomass as a Renewable Energy Source. 2004. Royal Commission on Environmental Pollution. www.rcep.org.uk/bioreport.htm

Biomass Program. 2006. U.S. Department of Energy. http://www.eere.energy.gov/biomass/

Biomass Program: Biomass Publications. 2005. US Department of Energy. http://www.eere.energy.gov/biomass/publications.html\#feed

Biomass Program: Feedstock Composition Glossary. 2005. US Department of Energy. http://www.eere.energy.gov/biomass/feedstock_glossary.html

Biomass Program Multi-Year Technical Plan. 2003. US Department of Energy. http://www.bioproducts-bioenergy.gov/pdfs/MYTP\%20FY\%202002\%20v13.pdf

Biomass Research. What is a Biorefinery? National Renewable Energy Laboratory. www.nrel.gov/biomass/biorefinery.html

Biomass Research and Development Act of 2000. Title III of the Agriculture Risk Protection Act of 2000 (Public Law 106-224). 2000. www.bioproducts-bioenergy.gov/bio_act.html

Chemicals Industry of the Future. 2005. US Department of Energy. http://www.eere.energy.gov/industry/chemicals/index.html

Chemical Industry Vision 2020. 2006. http://www.chemicalvision2020.org/

CoProducts and Near CoProducts of Fuel Ethanol Fermentation from Grain. 1996. Tibelius, C. http://res2.agr.ca/publications/cfar/index_e.htm

Feed Co-Products of the Dry Corn Milling Process. 2005. Weigel, J., D. Loy. and L. Kilmer. http://www.iowacorn.org/forms/drymillbook.pdf

Industrial Bioproducts: Today and Tomorrow. 2003. Energetics Incorporated / US Department of Energy. www.bioproductsbioenergy.gov/pdfs/BioProductsOpportunitiesReportFinal.pdf

Outlook for Biomass Ethanol Production and Demand. 2000. DiPardo, J. http://www.eia.doe.gov/oiaf/analysis.htm

The Biomass Economy. 2002. National Renewable Energy Laboratory. www.nrel.gov/docs/gen/fy04/36369.pdf

Top Value Added Chemicals from Biomass. 2004. Werpy, T. and G. Peterson, eds. US Department of Energy. http://www.nrel.gov/docs/fy04osti/35523.pdf

Roadmap for Agricultural Biomass Feedstock Supply in the United States. 2003. US Department of Energy. www.eere.energy.gov/biomass/publications.html\#feed

Roadmap for Biomass Technologies in the United States. 2002. Biomass Technical Advisory Committee. www.bioproducts-bioenergy.gov/pdfs/FinalBiomassRoadmap.pdf Vision for Bioenergy \& Biobased Products in the United States. 2002. Biomass Technical 
Advisory Committee. www.bioproducts-bioenergy.gov/pdfs/BioVision_03_Web.pdf

\section{Curriculum Incorporation Strategies}

Over the years engineering and technology programs, especially those related to manufacturing and associated disciplines, have primarily focused on traditional materials and processes. Even though technology has been constantly improving, the U.S. manufacturing industry base has suffered substantially in recent years due to changes in international trade policies. Bio-based manufacturing offers one potential route to alleviate some of these pressures in the global marketplace. But, up to this point in time, bio-based manufacturing has been largely ignored by most educational programs. In fact, only a few studies have examined their potential to augment existing curricula [54-57]; none of these have been comprehensive in nature. In this emerging area, many opportunities currently exist to infuse undergraduate curricula with cutting-edge science, not only in terms of curricular augmentation, but also as a chance for faculty to develop truly innovative teaching materials.

To adequately cover the extensive range of topics relevant to this proposal, the authors recommend a full-semester stand-alone course dedicated to the processing of biological materials. Ideally, this would be implemented in a lecture/lab format, so that the various learning styles of both engineering and technology students alike can be addressed. Core topics for such a course could include processing biomass into bio-based energy, chemicals, transportation fuels, and manufactured products, with an emphasis on product design considerations and necessary unit operations; economic analysis of bioprocesses; and environmental impacts of these operations. In conjunction with the other topics discussed in this paper, these could be readily converted into a course syllabus. Moreover, not only will students require theoretical and technical knowledge, they will also need hands-on, applied experiences to have a meaningful education in these biological areas - disciplines in which most students will have little experience. Thus laboratory exercises and infrastructure will be keys to the success of such an effort, and warrant a follow-up article to discuss them thoroughly.

Furthermore, the development of this type of course could even provide a basis for an engineering or technology program to offer a minor in bioprocessing. This would, however, require additional supporting coursework. Some of these could include biology, inorganic chemistry, organic chemistry, biochemistry, biotechnology, plant science, and industrial microbiology.

Understandably, not all academic programs will be able to accommodate the addition of another course with all other programmatic requirements currently in place. Therefore, it is beneficial to examine other mechanisms for incorporating biological and bioprocessing instruction, either as individual topics, components, or units that can be used as specific learning modules, into existing coursework. Many approaches have been found to be quite successful vis-à-vis augmenting engineering and technology instruction by inserting additional materials into mainstream instruction [58]. Addressing engineering ethics is a prime example. Some avenues 
that have been shown to work well include integrating focused components (theory as well as case study analyses) into specific technical courses [59-63], examining issues during technical problem solving in specific technical courses [64], issues and topics for review during capstone experiences [65-66], specific components in coursework dedicated to professionalism [67-68], topical seminars [69], as well as integration throughout the entire curriculum [70-72]. Ultimately, the successful inclusion of biological concepts in undergraduate engineering and technology education will be dependent upon individual faculty interest, motivation, and implementation, and will be heavily influenced by the creativity of the instructor.

\section{Conclusions}

Curriculum changes depend on, and must meet the needs of, each academic program's constituents and stakeholders. It is becoming apparent that biorenewable resources and their utilization for power, transportation fuels, and manufactured products are becoming a very relevant topic today, and will continue to become even more so as we move into the $21^{\text {st }}$ Century and continue to tax the Earth's resources. This paper has been intended to introduce engineering and technology educators to opportunities related to emerging bio-based industries. Essential concepts have been discussed, as have the relevance to engineering and technology education, and curriculum infusion techniques. Although it is not completely comprehensive in nature,

many references have been included, so educators should find this a useful resource base from which to work.

\section{References}

1. EIA AEO. 2004. Annual Energy Outlook 2004. U.S. Department of Energy, Energy Information Administration.

2. Fischer, G. and L. Schrattenholzer. 2001. Global bioenergy potentials through 2050. Biomass and Bioenergy 20: 151-159.

3. Brown, R.C... 2003. Biorenewable Resources - Engineering New Products from Agriculture. Blackwell Publishing Co. New York, NY

4. Hoogwikjk, M., A. Faaij, R. Van den Broek, G. Berndes, D. Gielen, and W. Turkenburg. 2003. Exploration of the ranges of the global potential of biomass for energy. Biomass and Bioenergy 25: 119-133.

5. Abbas, C. A. and M. Cheryan. 2002. Emerging biorefinery opportunities. Applied Biochemistry and Biotechnology 98-100: 1147.

6. Audsley, E. and J. E. Annetts. 2003. Modeling the value of a rural biorefinery - part I: the model description. Agricultural Systems 76: 39-59.

7. Annetts, J. E. and E. Audsley. 2003. Modeling the value of a rural biorefinery - part II: analysis and implications. Agricultural Systems 76: 61-76.

8. Gravitis, J., J. Zandersons, N. Vedernikov, I. Kruma, and V. Ozols-Kalnins. 2004. Clustering of bio-products technologies for zero emissions and eco-efficiency. Industrial Crops and Products 20: 169-180.

9. Kamm, B., and M. Kamm. 2004a. Biorefinery systems. Chem. Biochem. Eng. Q. 18(1): 1-6.

10. Kamm, B. and M. Kamm. 2004b. Principles of biorefineries. Applied Microbiology and Biotechnology 64: 137-145.

11. Ohara, H. 2003. Biorefinery. Applied Microbiology and Biotechnology 62: 474-477.

12. McKendry, P. 2002. Energy production from biomass (part 1): overview of biomass. Bioresource Technology 83: 37-46. 
13. Dien, B. S., L. B. Iten, C. D. Skory. 2005. Converting Herbaceous Energy Crops to Bioethanol: A Review with Emphasis on Pretreatment Processes. In: Handbook of Industrial Biocatalysis, Chapter 23. Boca Raton, Fl: Taylor \& Francis Group.

14. Lynd, L. R. 1996. Overview and evaluation of fuel ethanol from cellulosic biomass: technology, economics, the environment, and policy. Annual Review of Energy and Environment 21: 403-465.

15. Watson, S. A. and P. E. Ramstad. 1987. Corn: Chemistry and Technology. St. Paul, MN: American Association of Cereal Chemists.

16. Wayman, M. and S. R. Parekh. 1990. Cereal grains. In Biotechnology of Biomass Conversion: Fuels and Chemical from Renewable Resources. Philadelphia, PA: Open University Press.

17. Amen-Chen, C., H. Pakdel, and C. Roy. 2001. Production of monomeric phenols by thermochemical conversion of biomass: a review. Bioresource Technology 79: 277-299.

18. Bridgewater, A. V. 2000. Fast pyrolysis processes for biomass. Renewable and Sustainable Energy Reviews 4: $1-73$.

19. Bridgewater, A. V., S. Czernik, J. Diebold, D. Meier, A. Oasmaa, C. Peacocke, J. Piskorz, and D. Radlein. 1999. Fast Pyrolysis of Biomass: A Handbook. Newbury, UK: CPL Press.

20. Bridgewater, A. V., A. J. Toft, and J. G. Brammer. 2002. A techno-economic comparison of power production b y biomass fast pyrolysis with gasification and combustion. Renewable and Sustainable Energy Reviews 6: 181-248.

21. Luo, Z., S. Wang, Y. Liao, J. Zhou, Y. Gu, and K. Cen. 2004. Research on biomass fast pyrolysis for liquid fuel. Biomass and Bioenergy 26: 455-462.

22. Scott, D. S. P. Majerski, J. Piskorz, and D. Radlein. 1999. A second look at fast pyrolysis of biomass - the RTI process. Journal of Analytical and Applied Pyrolysis 51: 23-37.

23. Zanzi, R., K. Sjostrom, and E. Bjornbom. 2002. Rapid pyrolysis of agricultural residues at high temperature. Biomass and Bioenergy 23: 357-366.

24. Annamalai, K., M. Sami, and M. Wooldrige. 2001. Co-firing of coal and biomass fuel blends. Progress in Energy \& Combustion Science 27: 171-214.

25. Borman, G. L. and K. W. Ragland. 1998. Combustion Engineering. McGraw-Hill.

26. Jenkins, B. M., L. L. Baxter, T. R. Miles, Jr., and T. R. Miles, Sr. 1998. Combustion properties of biomass. Fuel Processing Technology 54: 17-46.

27. Dasappa, S., H. V. Sridhar, G. Sridhar, P. J. Paul, and H. S .Mukunda. 2003. Biomass gasification - a substitute to fossil fuels for heat application. Biomass and Bioenergy 25: 637-649.

28. McKendry, P. 2002. Energy production from biomass (part 3): gasification technologies. Bioresource Technology 83: 55-63.

29. Reed, T. 1981. Biomass Gasification: Principles and Technology. Park Ridge, NJ: Noyes Data Corporation.

30. Warnecke, R. 2000. Gasification of biomass: comparison of fixed bed and fluidized bed gasifier. Biomass and Bioenergy 18: 489-497.

31. Belgiorno, V., G. De Feo, C. Della Rocca, and R. M. A. Mapoli. 2003. Energy from gasification of solid wastes. Waste Management 23: 1-15.

32. Brammer, J. G. and A. V. Bridgewater. 1999. Drying technologies for an integrated gasification bio-energy plant. Renewable and Sustainable Energy Reviews 3: 243-289.

33. Cummer, K. R. and R. C. Brown. 2002. Ancillary equipment for biomass gasification. Biomass and Bioenergy 23: 113-128.

34. Kashyap, D. R., K. S. Dadhich, and S. K. Sharma. 2003. Biomethanation under psychrophilic conditions: a review. Bioresource Technology 87: 147-153.

35. Klass, D. L. 1998. Biomass for Renewable Energy, Fuels, and Chemicals. San Diego, CA: Academic Press.

36. Rajeshwari, K. V., M. Balakrishnan, A. Kansal, K. Lata, and V. V. N. Kishore. 2000. Renewable and Sustainable Energy Reviews 4: 135-156.

37. Rao, M. S. and S. P. Singh. 2004. Bioenergy conversion studies of organic fraction of MSW: kinetic studies and gas yield-organic loading relationships for process optimization. Bioresource Technology 95: 173-185.

38. Speece, R. E. 1996. Anaerobic Biotechnology for Industrial Wastewaters. Nashville, TN: Archae Press.

39. DiPardo, J. 2000. Outlook for biomass ethanol production and demand. U.S. Department of Energy, Energy Information Agency. [Online] URL: http://www.eia.doe.gov/oiaf/analysis.htm.

40. Dien, B. S., R. J. Bothast, N. N. Nichols, and M. A. Cotta. 2003. The U.S. corn ethanol industry: an overview of current technology and future prospects. In The Third International Starch Technology Conference Coproducts Program Proceedings, eds. M. Tumbleson, V. Singh, and K. Rausch, 2-4 June, 2003, University of Illinois, pp. 10-21. 
41. Jaques, K. A., T. P. Lyons, and D. R. Kelsall. 2003. The Alcohol Textbook. Nottingham University Press: Nottingham, UK.

42. Tibelius, C. 1996. Coproducts and Near Coproducts of Fuel Ethanol Fermentation from Grain. Agriculture and Agri-Food Canada - Canadian Green Plan Ethanol Program: Starchy Waste Streams Evaluation Project. [Online] URL: http://res2.agr.ca/publications/cfar/index_e.htm.

43. Weigel, J. C., D. Loy, and L. Kilmer. 2005. Feed Co-Products of the Dry Corn Milling Process. Iowa State University and Iowa Corn Promotion Board. [Online] URL: www.iowacorn.org/ethanol/ethanol_17.html.

44. Carter, D. and J. Halle. 2005. How to Make Biodiesel. Low-Impact Living Initiative

45. Knothe, G. 2005. The Biodiesel Handbook. AOCS Press.

46. Pahl, G. 2005. Biodiesel: Growing a New Energy Economy. Chelsea Green Publishing Company.

47. Bozell, J. J. and R. Landucci. 1993. Alternative Feedstocks Program Technical and Economic Assessment: Thermal/Chemical and Bioprocessing Components. Washington, D.C.: U.S. Department of Energy.

48. Kamm, B., M. Kamm, M. Schmidt, I. Starke, and E. Kleinpeter. 2005. Chemical and biochemical generation of carbohydrates from lignocellulose-feedstock (Lupinus nootkatensis) - quantification of glucose. In press.

49. Rowell, R. M., T. P. Schultz, and R. Narayan. 1992. Emerging Technologies for Material and Chemicals from Biomass. ACS Symposium Series 476. Washington, D.C.: American Chemical Society.

50. Stevens, E. S. 2002. Green Plastics: An Introduction to the New Science of Biodegradable Plastics. Princeton, NJ: Princeton University Press.

51. Rosentrater, K. A. and A. W. Otieno. 2005. Essential considerations for manufacturing products containing biomaterials. ASAE Paper No.: MC05-406. St. Joseph, MI: American Society of Agricultural Engineers.

52. Rowell, R. M. 1992. Opportunities for lignocellulosic materials and composites. In Emerging Technologies for Materials and Chemical from Biomass, ACS Symposium Series 476. Washington, D.C.: American Chemical Society.

53. Rowell, R. M., R. A. Young, and J. R. Rowell. 1997. Paper and Composites from Agro-Based Resources. CRC Press.

54. Stephens, M. P. and N. Latif. 2005. A cross-disciplinary biotechnology initiative: a new frontier for industrial technology. Journal of Industrial Technology 21(1): 1-5.

55. Jones, C., R. Rogers, and J. Anderson. 2005. Integrating a renewable energy degree into an existing mechanical engineering program. Proceedings of the 2005 American Society for Engineering Education Annual Conference \& Exposition.

56. Mohan, M. A., N. May, N. M. Assaf-Anid, and M. J. Castaldi. 2005. Biomass as an alternative energy source: an illustration of chemical engineering thermodynamic concepts. Proceedings of the 2005 American Society for Engineering Education Annual Conference \& Exposition.

57. Glatz, C., B. Narasimhan, J. Shanks, M. Huba, K. Saunders, P. Reilly, and S. Mallapragada. 2004. Problembased learning laboratories involving chemicals from biorenewables. Proceedings of the 2004 American Society for Engineering Education Annual Conference \& Exposition.

58. Dyrud, M. Ethics education for the third millennium. 1998. Proceedings of the 1998 American Society for Engineering Education Annual Conference \& Exhibition. Session 1347.

59. Alenskis, B. A. 1997. Integrating ethics into an engineering technology course: an interspersed component approach. Proceedings of the 1997 American Society for Engineering Education Annual Conference \& Exhibition. Session 2247.

60. Arnaldo, S. 1999. Teaching moral reasoning skills within standard civil engineering courses. Proceedings of the 1999 American Society for Engineering Education Annual Conference \& Exhibition. Session 1615.

61. Case, E. 1998. Integrating professional ethics into technical courses in materials science. Proceedings of the 1998 American Society for Engineering Education Annual Conference \& Exhibition, Session 1664.

62. Krishnamurthi, M. 1998. Integrating ethics into modeling courses in engineering. Proceedings of the 1998 American Society for Engineering Education Annual Conference \& Exhibition. Session 2461.

63. Whiting, W., J. Shaeiwitz, R. Turton, and R. Cailie. 1998. 1998 ASEE Annual Conference Proceedings, Session 2213.

64. Rabins, M., C. Harris, J. Hanzlik. 1996. An NSF/Bovay endowment supported workshop to develop numerical problems associated with ethics cases for use in required undergraduate engineering courses. 1996 ASEE Annual Conference Proceedings, Session 3332.

65. Pappas, E. and J. Lesko. 2001. The communication-centered senior design class at Virginia Tech. Proceedings of the 2001 American Society for Engineering Education Annual Conference \& Exhibition, Session 1161.

66. Soudek, I. 1996. Teaching ethics to undergraduate engineering students: understanding professional responsibility through examples. 1996 ASEE Annual Conference Proceedings, Session 1661. 
67. Bhatt, B. L. 1993. Teaching professional ethical and legal aspects of engineering to undergraduate students. 1993 ASEE Frontiers in Education Conference Proceedings, p. 415-418.

68. Fulle, R., C. Richardson, G. Zion. 2004. Building ethics and project management into engineering technology programs. Proceedings of the 2004 American Society for Engineering Education Annual Conference \& Exhibition, Session 1348.

69. Alford, E. and T. Ward. 1999. Integrating ethics into the freshman curriculum: an interdisciplinary approach. Proceedings of the 1999 American Society for Engineering Education Annual Conference \& Exhibition. Session 2561.

70. Marshall, J. and J. Marshall. 2003. Integrating ethics education into the engineering curriculum. Proceedings of the 2003 American Society for Engineering Education Annual Conference \& Exhibition. Session 1675.

71. Davis, M. 1992. Integrating ethics into technical courses: IIT's experiment in its second year. 1992 ASEE Frontiers in Education Conference Proceedings, p. 64-68.

72. Leone, D. and B. Isaacs. 2001. Combining engineering design with professional ethics using an integrated learning block. Proceedings of the 2001 American Society for Engineering Education Annual Conference \& Exhibition. Session 2525.

73. Shewhart, W. A. 1996. Statistical Method from the Viewpoint of Quality Control. Dover Publications.

74. Shewhart, W. A. 1980. Economic Control of Quality of Manufactured Product. American Society for Quality. 75. Taguchi, G., S. Chowdhury, and Y. Wu. 2004. Taguchi's Quality Engineering Handbook. Wiley-Interscience. 